the present interglacial. This suggests that prehistoric man may have resorted to coal at specific times of climate and forest regression, while using wood for preference.

I. Théry*, J. Gril†, J. L. Vernet*, L. Meignenキ, J. Maury§

* Laboratoire de Paléobotanique, Environnement et Archéologie, URA CNRS 1477,

†Laboratoire de Mécanique

et Génie Civil, URA CNRS 1214 ,

Université de Montpellier II,

34095 Montpellier Cedex 05

†ERA 28, Prehistoire et Technologie,

CRA-CNRS Sophia-Antipolis 06560

$\S 13$ Cité Beausoleil,

12740 Sébazac,

France

\section{A tombstone in Alzheimer's?}

SIR - Harrington and Colaco in News and Views ${ }^{1}$ considered recent intriguing studies providing evidence for glycation of amyloid- $\beta$ protein $(A \beta)$ and tau protein in Alzheimer's disease. $A \beta$ and tau form the insoluble filamentous aggregates that comprise plaques and neurofibrillary tangles, respectively, in the brains of Alzheimer patients. Harrington and Colaco suggested that glycation of $A \beta$ and tau may be causally involved in the neurodegeneration associated with $\mathrm{A} \beta$ and tau.

Nevertheless, additional findings to those discussed by Harrington and Colaco suggest that glycation of $A \beta$ probably occurs after crosslinking of the peptide and after $A \beta$ has damaged neurons. First, synthetic $A \beta$ forms fibrillar aggregates in the absence of sugars (without glycation) $)^{2,3}$. Second, synthetic (unglycated) $A \beta$ can damage and kill neurons in culture, and its neurotoxic potency is correlated with its ability 'spontaneously' to form aggregates $^{2-4}$. Third, when synthetic $A \beta$ is placed in physiological saline (in the absence of sugars) it generates free radical peptides that can directly damage enzymes ${ }^{5}$, and induce accumulation of reactive oxygen species in cultured

1. Harrington, C. R. \& Colaco, C. A. L. S. Nature $\mathbf{3 7 0}$ 247-248 (1994).

2. Pike, C. J. et al. J. Neurosci. 13, 1676-1687 (1993)

3. Mattson, M. P., Tomaseili K. \& Rydel, R. E. Brain Res. 621, 35-49 (1993).

4. Yankner, B. A., Duffy, L. K. \& Kirschner, D. A. Science 250, 279-282 (1990).

5. Hensley, K. et al. Proc. natn. Acad. Sci. U.S.A. 91, 3270-3274 (1994).

6. Goodman, Y. \& Mattson, M. P. Expl Neurol. 128, 1-12 (1994).

7. Behl, C., Davis, J. B., Lesley, R. \& Schubert, D. Cell 77, 817-827 (1994)

8. Butterfield, D. A. et al. Biochem. biophys. Res. Commun. 200, 710-715 (1994)

9. Vitek, M. P. et al. Proc. natn. Acad. Sci. U.S.A. 91 , 4766-4770 (1994).

10. Smith, M. A. et al. Proc. natn. Acad. Sci. U.S.A. 91 5710-5714 (1994).

11. Yan, S.-D. et al. Proc. natn. Acad, Sci. U.S.A. 91. 7787-7791 (1994). neurons $^{6,7}$ and synaptosomes ${ }^{8}$. Fourth, studies of different $A \beta$ fragments indicate that generation of free radical peptides correlates directly with aggregation kinetics (ref. 5). Fifth, although recent glycation connection studies ${ }^{9-11}$ provide strong evidence for the presence of advanced glycation end products in 'mature' plaques and tangles (comprised of aggregated $A \beta$ and tau, respectively), they did not reveal whether advanced glycation end-products are present in 'immature' plaques and tangles before formation of $A \beta$ and tau aggregates. If glycation is causally involved in the neuronal injury and death process, then glycation would be expected to occur early in the disease process.

We propose that glycation of $A \beta$ is a late event in the evolution of Alzheimer's disease and results from free radical generation by $A \beta$ itself. In this view, agerelated changes in the brain, including reduced energy availability and an oxidizing environment, combine to promote radicalization of $A \beta$. $A \beta$ radicals promote covalent crosslinking of the peptide, and propagate radicals to cell membranes. The peptide-associated radicals would also promote crosslinking of the peptide to sugars, resulting in glycation.

Mark P. Mattson*, John W. Carney $†$,

\section{Allan Butterfield $\neq$}

*Sanders-Brown Research Center

on Aging and Department of Anatomy and Neurobiology,

† Department of Pharmacology,

₹Center of Membrane Sciences and

Department of Chemistry,

University of Kentucky,

Lexington, Kentucky 40536, USA

\section{Calcium entry signal?}

SIR - Randriamampita and Tsien' reported that acid extracts of Jurkat $\mathrm{T}$ cells contain a $\mathrm{Ca}^{2+}$-entry-stimulating factor that they concluded is the messenger for capacitative $\mathrm{Ca}^{2+}$ entry, and which they termed $\mathrm{CIF}\left(\mathrm{Ca}^{2+}\right.$-influx factor). Because of the potential significance of this discovery ${ }^{2-5}$, we have further examined the effects of this material on $\mathrm{Ca}^{2+}$ signalling. Our findings demonstrate that this activity is unlikely to be the elusive cellular messenger for capacitative $\mathrm{Ca}^{2+}$ entry.

We prepared an extract of Jurkat cells following the procedure outlined in ref. 1 , and tested its effects on fura-2-loaded $1321 \mathrm{~N} 1$ astrocytoma cells. This extract caused an elevation of intracellular $\mathrm{Ca}^{2+}$ which was due to $\mathrm{Ca}^{2+}$ entry, usually accompanied by irregular oscillations $(b$ in the figure). In unstimulated Jurkat cells, all the activity was in the particulate fraction of the cells, and on stimulation with phytohaemagglutinin, activity was

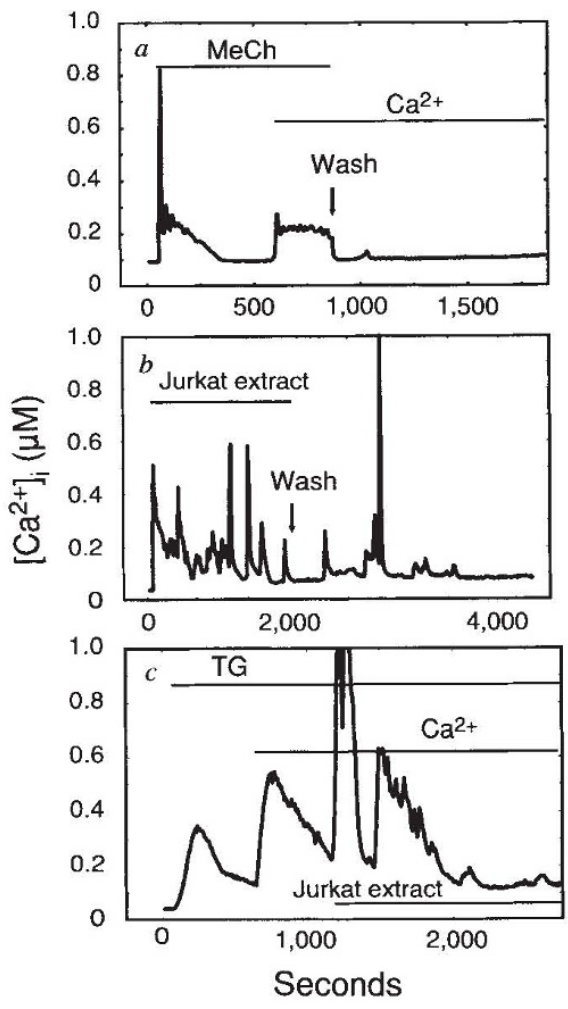

Calcium responses of $1321 \mathrm{~N} 1$ astrocytoma cells to methacholine, Jurkat extract and thapsigargin. $a$ and $b$, Single fura-2-loaded astrocytoma cells stimulated with either $100 \mu \mathrm{M}$ methacholine (initially in the absence of external $\mathrm{Ca}^{2+}$, with $\mathrm{Ca}^{2+}$ added to the medium where indicated; a) or Jurkat extract (b). After establishing a sustained $\mathrm{Ca}^{2+}$ response in both instances, stimuli were removed by exchanging the bathing solution. Shown are representative traces from 3 similar experiments. $c$, After establishing a $\left[\mathrm{Ca}^{2+}\right]$, response to thapsigargin $(2 \mu \mathrm{M})$ followed by addition of extracellular $\mathrm{Ca}^{2+}$ in a single fura-2-loaded astrocytoma cell, the Jurkat extract was added in the continued presence of thapsigargin. Shown are representative traces from 8 similar experiments. $\mathrm{Ca}^{2+}$ signalling in single astrocytoma cells was measured as described $^{7}$. Jurkat extract was prepared as in ref. 1.

released into the soluble fraction. These findings reproduce those of Randriamampita and Tsien, and indicate that our Jurkat extract contains the same $\mathrm{Ca}^{2+}$. mobilizing principle described in their paper as CIF.

As $\mathrm{Ca}^{2+}$ signalling is a rapidly reversible response, so too should be the actions of intracellular mediators of $\mathrm{Ca}^{2+}$ signalling. But after washout of the Jurkat extract from astrocytoma cells, the $\left[\mathrm{Ca}^{2+}\right]_{\mathrm{i}}$ signals persisted for up to $30 \mathrm{~min}(b$ in the figure). By contrast, after washout of

\footnotetext{
1. Randriamampita, C. \& Tsien, R. Y. Nature 364, 809-814 (1993).

2. Clapham, D. Nature 364, 763-764 (1993).

3. Putney, J. W. Jr \& Bird, G. S. J. Cell 75, 199-201 (1993)

4. Putney, J. W. Jr Science 262, 676-678 (1993)

5. Meldolesi, J. Curr. Biol. 3, 910-912 (1993).

6. Kwan, C. Y. et al. Am. J. Physiol. 258, C1006-C1015 (1990)

7. Bird, G. S. J. et al. Nature 352, 162-165 (1991).
} 